\title{
A CAPITAL OPPORTUNITY: CREATING A NEW ZEALAND JURISPRUDENCE IN PUBLIC AND INTERNATIONAL LAW
}

\author{
Hon David Baragwanath*
}

\begin{abstract}
This is the written form of a lecture delivered at the Law Faculty on 28 April 2010 by Justice Baragwanath as part of a series of lectures delivered the various New Zealand law schools, to mark the judge's retirement from the New Zealand Court of Appeal. In this lecture the judge argues for the creation of a New Zealand public law that both acknowledges the special nature of New Zealand society and recognises the global context within which all New Zealand law must now fit and to some extent must be judged.
\end{abstract}

\section{THE TOPIC}

I express my thanks to Dean Tony Smith for this opportunity to address you. ${ }^{1}$ This is the third of a series of lectures about the creation of a New Zealand jurisprudence. The first, in Auckland, looked at the differences between English and New Zealand attitudes to tax avoidance. ${ }^{2}$ The second, last week in Dunedin, examined private law. ${ }^{3}$ It is appropriate in Wellington to consider the contribution of the bar and the judges, and the Academy as their critics, consciences and mentors, to

* The Hon David Baragwanath QC retired from the Court of Appeal in August 2010. He has long been interested in domestic public law and in public and private international law. As President of the New Zealand Law Commission he was responsible for its work in these areas on which he has also delivered significant judgments. He is currently a judge of the Appeals Chamber of the Special Tribunal for Lebanon, a New Zealand member of the Permanent Court of Arbitration and presiding judge in the Court of Appeal of Samoa.

1 Dean Smith's manifold contributions to New Zealand jurisprudence include the valuable table taken from Arlidge, Eady and Smith On Contempt (3rd ed, Sweet \& Maxwell, London, 2005) which shed light on whether the continued detention of the appellant in Chief Executive of the Department of Labour v Yadegary [2008] NZCA 295, [2009] 2 NZLR 495 was reasonable: see at [64].

2 David Baragwanath "Commerce, Morality and the Law" (Lecture to Auckland University of Technology Law School, 13 February 2010).

3 David Baragwanath "A Second-hand Rose? Creating a New Zealand Jurisprudence" (Lecture to University of Otago Law School, 23 April 2010). 
developing and applying the common law that governs those responsible for government and foreign relations. It touches on two aspects:

- $\quad$ our domestic public law

- $\quad$ how we view and deal with disputes with an international dimension.

\section{THE NEED FOR IMPROVEMENT}

In a perceptive essay, my copy of which is among my debts to Professor Angelo, Dr Nigel Jamieson referred to: ${ }^{4}$

New Zealand's brief entry into Europe (1840-1947), via Britain instead of via France, [which]

incorporates European and British history into New Zealand's history.

In the case of the courts our membership of Europe extended a further seven decades until 1 July 2004, when a New Zealand court was permitted for the first time to determine the fate of New Zealand cases.

Having argued many years ago for retention to the Privy Council, and later for its abolition, in 2003 I contended that after the switch from the Privy Council we should seek cohesion with the United Kingdom and other Commonwealth states. ${ }^{5}$ I claim in this address that the reform has wrought a fundamental change to the role and function of the New Zealand courts - not just the Supreme Court - and likewise to that of the profession and the Academy. I confess I am only now beginning to appreciate the need and urgency of such a changed approach.

In New Zealand, as elsewhere, the primary elements of constitutional process include the judiciary's administration of the criminal law and judicial review of public sector conduct. This paper asserts a pressing need to improve our public law, contributing to its development for the benefit of all New Zealanders and others beyond:

(1) by identifying and casting out relicts of hand-me-down laws that are alien to our conditions; and

(2) by reaching out and adopting from any source whatever ideas, including the unfamiliar, which will suit our needs.

These changes must occur both domestically and in terms of the international component of our public law.

These conclusions have been reinforced for me recently by four otherwise unrelated events.

4 Dr Nigel Jamieson "Talking Through the Treaty" (2005) 11 Revue Juridique Polynésienne/NZACL Yearbook 2004101 at 118

5 David Baragwanath "Putting away childish things: an argument for cohesion after the Privy Council" (2003) 3 Oxford University Commonwealth Legal Journal 225. 


\section{A Domestic: Expelling Alien Notions}

The first was finalising judgment in Sunset Terraces $^{6}$ upon the role and responsibility of local authorities in the claims against them by owners and occupiers of leaky apartment blocks. The case ${ }^{7}$ revealed just how during the 170 years since 1840 New Zealand and England have become different societies, both in fact and, importantly, in certain perceptions of their judges. What they see as an economic investment we have characterised as a New Zealander's right to shelter and habitation. ${ }^{8}$

The second event was the Congress, in Sydney and Canberra, of the International Association of Supreme Administrative Court Jurisdictions (IASAJ). Judges from more than 50 states were present, embracing each continent and the world's major legal systems. The IASAJ Congress was of great interest, not least because the community of opinion as to the issues and their resolution was remarkable. The participants included the senior members of the French Conseil d'État; the Senior President of Tribunals of England and Wales; members of the Federal Court of Appeal of Canada; members of the Federal Court of Australia; and their equivalents from other states of the civil law, the common law and indeed the Shari'a. ${ }^{9}$ The atmosphere was dynamic. I learned, for example, that judicial review in China is only six years old. But it was striking to see the careful heed paid by the six final administrative judges from that state, which will be crucial to our future, to all aspects of the discussion. Following as it does China's entry into the World Trade Organisation, with its compulsory dispute resolution procedures, the event showed how seriously they are taking fundamental aspects of the rule of law.

The over-arching theme of the Congress topic - jurisdiction and competency - was the principle that judges must restrain unreasonable public sector conduct whether by the Executive or, in almost all states other than New Zealand, by the Legislature. Indeed the vigour and unanimity of the approach by judges of so many states, many lacking New Zealand's rule of law traditions, presented a real challenge to our own performance. We cannot afford to take our own virtue for granted and this international benchmarking is salutary.

In that respect you would have found pleasing the close attention paid by the meeting to New Zealand's acceptance of the variable intensity approach to judicial review, ${ }^{10}$ which the English seem

$6 \quad$ Sunset Terraces [2010] NZCA 64, [2010] 3 NZLR 486.

7 For which leave to appeal to the Supreme Court has been granted.

8 In Commerce, Morality and the Law, above n 2, I referred to the difference between New Zealand and English attitudes to tax avoidance.

9 Including judges from Egypt, Indonesia and Tunisia. It may be noted that Rex Ahdar and Nicholas Aroney have edited Shari'a in the West (Oxford University Press, forthcoming).

10 See Air New Zealand Ltd v Wellington International Airport Ltd [2009] NZCA 259, [2009] 3 NZLR 713 at [147] [Air New Zealand]. Justice Arnold has recounted the discussion at the recent Auckland/Wellington conference of Professor Taggart's rainbow of variable intensity of review, including Mary Scholtens' chart of 12 specimen cases. 
to have slid into proportionality, a BAILII search reveals no appellate discussion of "variable intensity" whereas "proportionality" has been considered sixteen times in the United Kingdom Supreme Court, not only in human rights decisions such as the housing case Manchester City Council v Pinnock, but in conventional judicial review such as $R$ (Electoral Commission) $v$ City of Westminster Magistrates Court. ${ }^{11}$ which differs from the binary test adopted in Canada ${ }^{12}$ and which has not been adopted in Australia. It was seen by senior participants as affording a principled approach to the topic. It is to feature on the next agenda of the Congress, in Colombia, at which I hope my successors will take a leading part.

Also of particular interest at the Congress was the development of cross-border judicial cooperation, to which I return in the international context.

\section{B International: Discerning Foreign Ideas of Value}

The third event - a visit to Sydney and Auckland from the United States, London, Paris and elsewhere of the American Bar Association International Law Exchange group - was a further highlight. Among these distinguished practitioners of international commercial law were the author of commercial paper issued by states which is valued at several trillion dollars, and Justice Scalia of the United States Supreme Court. At our round table in Auckland under Chatham House rules they debated and agreed upon the pressing need for a seamless world view of law and litigation. The event is to be followed later in the year by a further roundtable discussion, this time in The Hague, at which specific proposals will be advanced. It concerns establishing another international tribunal - an International Dispute Resolution Facility for Financial Markets - in order to improve access to justice. $^{13}$

The event and discussion surrounding it bore out the rapidity of international developments. A mutual effort to resolve international disputes has travelled very fast since I wrote about crossborder judicial co-operation in 2004. ${ }^{14}$ Professor McLachlan's Lis Pendens in International Litigation $^{15}$ illustrates both the burgeoning need to respond to that development and some means by

11 Manchester City Council v Pinnock [2010] UKSC 45; $R$ (Electoral Commission) v City of Westminster Magistrates Court [2010] UKSC 40; and Michael Taggart Australian Exceptionalism in Judicial Review (2008) 36 Federal LR 1 at 24

12 Dunsmuir v New Brunswick [2008] 1 SCR 190.

13 That roundtable took place in October where I was privileged to be in The Hague among sixty experts whose discussion was chaired by Lord Woolf. The success of the event will lead to specific arrangements which are now in preparation.

14 [2004-5] Inner Temple Yearbook. A recent contribution is Wessells, Markell and Kilborn International Cooperation in Bankruptcy and Insolvency Matters (Oxford University Press, Oxford, 2009).

15 Campbell McLachlan Lis Pendens in International Litigation (Hague Academy of International Law, The Hague, 2009). 
which that may be done. The Hague initiative includes response to themes raised in his earlier book McLachlan, Shore and Weiniger International Investment Arbitration: Substantive Principles. ${ }^{16}$ The case of disputes under Bilateral Investment Treaties is of special interest, requiring the judges or arbitrators to participate in the development of public international law, as for example by determining whether the investor party can constrain the state in which the investment is made from undertaking resource protection measures that would bear upon it. ${ }^{17}$ The jurisprudence is growing rapidly but is need of urgent and principled development. That will be assisted by the forthcoming Hague Facility.

The bombing of Laos during the Vietnam war took place while my generation were students. It is a communist country trying hard to cast off impoverishment. On our last visit, Easter 2010, we went to Phonsaly in the far north. The treatment of state borders presented a striking contrast with a more familiar example. In the leading case Mitchell $v$ Canada ${ }^{18}$ Binnie $\mathrm{J}$ had declined to recognise a right, claimed by Indian tribes, to cross the Canada-United States border without paying customs duty. The ratio of his judgment was that the creation of sovereignty in each of those two states had annihilated the aboriginal rights. But in the far north of Laos the authorities of that state and China have acknowledged the entitlement of local people, on both sides of the Laos-China border, to move back and forth without the constraints imposed on others. The arrangement indicates that in this respect both communist states regard indigenous rights as warranting serious recognition, a topic under examination elsewhere.

These examples are among an increasing number of pointers to what I suggest is the development of two broad and simple themes:

(1) domestically, judicial review on the procedural ground of unreasonableness, together with the substantive element of dignity of the individual, are now a basic expression of the rule of law; and

(2) internationally, it is the function of states and courts to act in aid of one another to further the rule of law and, where that is not feasible, other dispute resolution systems must be created.

Within the domestic and international themes I have identified four overarching principles given effect by three elements of judicial review.

16 Campbell McLachlan, Laurence Shore and Matthew Weiniger International Investment Arbitration: Substantive Principles (Oxford University Press, Oxford, 2007).

17 I owe to David Williams QC, himself a distinguished international arbitrator, a reference to a penetrating overview by Benedict Kingsbury and Stephan Schill "Investor-State Arbitration as Governance: Fair and Equitable Treatment, Proportionality and the Emerging Global Administrative Law" in Albert Jan van den Berg 50 Years of the New York Convention (Kluwer Law International, London, 2009) 5.

18 Mitchell v Canada [2001] 1 SCR 911. 


\section{THE DOMESTIC SCENE}

\section{A Overarching Principles}

Both the formulation of the judge-made common law of judicial review, facilitated as it is by the Judicature Amendment Act 1972, and its exercise by judges entail the application of overarching principles. These are:

- It is for the judiciary to identify and state the relevant principles of law;

- the fundamental principle is that of legality; ${ }^{19}$

- It is the further task of the judiciary to grant appropriate relief against illegality;

- Throughout the process the judges must maintain the sense of proportion which is required for any decision to be respected. Here "proportionality" is not a term of art but an expression of wise judgment.

At the heart of judicial review lie three elements:

(1) the difference between the role of the state and that of others;

(2) the basis for judicial review; and

(3) "discretion".

\section{The difference between the role of the state and that of others}

The first element is the difference between the role of the state and that of others. The need to get rid of alien notions is not easy when we have been brought up to see them as basics. Take the English jurisprudence about the protection of the state.

19 The most familiar example, Sir Rupert Cross's formulation, has gained prominence from its adoption in leading cases. It is cited in $R v$ Secretary of State for the Home Department ex parte Pierson [1998] 1 AC $539(\mathrm{HL})$ at 588 per Lord Steyn:

Statutes often go into considerable detail, but even so allowance must be made for the fact that they are not enacted in a vacuum. A great deal inevitably remains unsaid. Legislators and drafters assume that the courts will continue to act in accordance with well-recognised rules . . Long-standing principles of constitutional and administrative law are likewise taken for granted, or assumed by the courts to have been taken for granted, by Parliament. Examples are the principles that discretionary powers conferred in apparently absolute terms must be exercised reasonably, and that administrative tribunals and other such bodies must act in accordance with the principles of natural justice. One function of the word 'presumption' in the context of statutory interpretation is to state the result of this legislative reliance (real or assumed) on firmly established legal principles. There is a 'presumption' that mens rea is required in the case of statutory crimes, and a 'presumption' that statutory powers must be exercised reasonably. These presumptions apply although there is no question of linguistic ambiguity in the statutory wording under construction, and they may be described as 'presumptions of general application'. ... These presumptions of general application not only supplement the text, they also operate at a higher level as expressions of fundamental principles governing both civil liberties and the relations between Parliament, the executive and the courts. They operate here as constitutional principles which are not easily displaced by a statutory text. 
It is striking that the very basis of the Crown-subject relationship, which still depends on a decision of Coke CJ in 1608, has never been seriously elucidated since. Ever since Calvin's Case, ${ }^{20}$ the subject's obligation of loyalty to the Crown has had a reciprocal of the Crown's obligation to protect its subjects. While authority for the former part exists at the highest level, ${ }^{21}$ apart from two dated essays by Sir John Salmond it is difficult to find such support for the latter. But I believe it is emerging. ${ }^{22}$ Nowadays in New Zealand we are coming to see not only that our fundamental value is that of the dignity of the individual but also that it is the state's role to promote that value. ${ }^{23}$ To discharge that function it is necessary to give additional authority to those who for a time are the human elements of the state: to parliamentarians the power to make laws; to the police, Corrections officers and the armed forces the power to use force; and so on. A topical question, for which the Supreme Court has given leave to appeal, is whether conduct of those exercising the judicial function can be the subject of a damages claim; or whether the nature of their functions requires exclusion of such remedy. ${ }^{24}$ There remains much work to get these things right. And in particular to do so from a New Zealand perspective.

In his Public Law chapter in the mighty Oxford History of the Laws of England Volumes XI, XII, and XIII 1820-1914, ${ }^{25}$ Professor Stuart Anderson has stripped away the errors that have for long underlain the English doctrine. As so often, Lord Mansfield saw the true position with clarity. In four perceptive judgments he rejected the notion that the Crown could do no wrong and gave judgment for plaintiffs against it. But his successors became lost in theory and restored the unprincipled constitutional defence, which Cromwell had demolished, that the Sovereign can do no wrong. It required a plaintiff injured by Crown conduct to make a humble Petition of Right to the Sovereign; a formula repeated by the compensation provision of the Foreshore and Seabed Act 2004 stating:

38 No redress other than that given by the Crown

(1) No claim may be made in respect of a finding made under section 33 other than redress-

(a) that the Crown may give ...; or

20 Calvin's Case (1604) 7 Coke Report 1a, 77 ER 377.

21 Joyce v DPP [1946] AC 347 (HL).

22 The topic is discussed in Ding v Minister of Immigration (2006) 25 FRNZ 568 (HC) at [227]-[243] (on appeal Ye v Minister of Immigration [2008] NZCA 291, [2009] 2 NZLR 596; and [2009] NZSC 76, [2010] 1 NZLR 104.

23 See for example Solicitor-General v Miss Alice [2007] 2 NZLR 783 (HC) at [42]-[49].

24 Attorney-General v Chapman [2009] NZCA 552, [2010] 2 NZLR 317.

25 John Baker (General Ed) Oxford History of the Laws of England (Oxford University Press, Oxford, 2004-). 
(b) provided in accordance with sections 40 to 43 (relating to the creation of foreshore and seabed reserves).

It is uncomfortable that the exclusion of access to the courts for relief mirrored the regime, struck down by the Constitutional Court of South Africa only eight months earlier, ${ }^{26}$ which had excluded judicial relief to indigenous people for expropriation of diamond bearing land. Fortunately, as the Waitangi Tribunal experience has shown, New Zealanders once aware of injustice are not infrequently able and willing to deal with it. The genius of Matui Rata's initiative was to discern the effect of simply putting the facts before the community.

Sometimes, however, the problem is too arcane for the ordinary New Zealander to appreciate. An example is the Crown Proceedings Act 1950 which, like the former Official Secrets Act, happily exposed by the Danks Committee, was first enacted in England and soon after in New Zealand. ${ }^{27}$

\section{The basis for judicial review}

The second element is - what is the basis for judicial review? For my generation of law students it was caught up with English procedural problems. The valuable Judicature Amendments Acts of 1972 and 1977 went far both to cut through the tangle and, of no less importance, to educate bar and bench that the complexity was not contributing to the delivery of justice. So Lord Cooke and his successors have achieved the great changes with which you are familiar. In Air New Zealand I offered the following opinion as to the basis of the jurisdiction: ${ }^{28}$

In Emmens v Pottle (1885) 16 QBD 354 (CA) Lord Esher MR stated of the common law at pp 357-358:

"The question does not depend on any statute, but on the common law, and, in my opinion, any proposition the result of which would be to shew that the Common Law of England is wholly unreasonable and unjust, cannot be part of the Common Law of England."

The common law Wednesbury principle adopts a similar approach to bodies exercising public powers which act unreasonably. The reason for that ground of judicial review of conduct by such bodies is that, like the common law, exercise of public authority is presumed not to lead to an unreasonable result. If the result is unreasonable the conduct will be declared unlawful because it is outside the legitimate

26 Alexkor Ltd v Richtersfeld Community [2003] ZACC 18.

27 Fortunately Professor Anderson has drawn it to public attention in his FW Guest Memorial Lecture 2008: Stuart Anderson "'Grave Injustice' 'Despotic Privilege': The Insecure Foundations of Crown Liability for Torts in New Zealand" (2009) 12 Otago LR 1. The decision of the Court of Appeal of England and Wales in Muuse v Home Secretary [2010] EWCA Civ 453 shows the interest of modern courts in the institutional Crown liability which is Professor Anderson's focus. The lesson of the Erebus Royal Commission is that we need to look in a similar direction. Dr Richard Ekins' current research assisted by a Marsden award will allow the Crown's role to be seen in clear perspective.

28 Air New Zealand, above n 10, at [155]-[156]. 
scope of what the statutory or common law (for example, prerogative) power permits. The principle has been updated by a series of decisions which recognise that the nature and intensity of review will depend on the context.

Because the principle is flexible, "unreasonable" receives a different construction in different classes of case: there is a continuum. In human rights cases the court will interfere if it disagrees on the merits of the decision $(R$ (Daly) $v$ Secretary of State for the Home Department [2001] 2 AC 532). In rating cases it will be slow to interfere but will do so on grounds of irrationality (Wellington City Council $v$ Woolworths New Zealand Ltd (No 2)).

It is now clear that the basis of jurisdiction, confirmed in s 16 of the Judicature Act 1908, lies in the inherent obligation of the judges to intervene against illegality of every kind in a manner suited to the conditions.

In doing so we can get much help from English authority, parts of it, like the Curate's Egg, being excellent. But other parts are nothing of the kind. These include some crabbed "rules" as to standing, to which I return. They also include what is unhappily called "discretion".

\section{3 "Discretion"}

The third element is that convenient but inadequate label, which is better termed "judgment". Again we can be helped or hindered by recourse to English cases. The great judges, like Lord Bingham, give exemplary leads. ${ }^{29}$ But in the end we must decide what is suited to our conditions.

In Minister of Conservation v Maori Land Court, ${ }^{30}$ I considered that final judgment could not be given until enough was known about the facts in order to exercise discretion. And in Combined Beneficiaries Union Incorporated v Auckland City COGS Committee, ${ }^{31} \mathrm{I}$ argued that for relief to be given, even by declaration, there must be sufficient substance in the case for the Court to be prepared to expose the opponent and the community, which bears cost in any proceeding, to the expenditure of time and effort that might be directed elsewhere.

I repeat in this context that the variable intensity of review approach has the advantage of dealing realistically with the spectrum of circumstances which fall for adjudication.

At one end is the basic human right of liberty, traditionally protected by habeas corpus. In such cases the judges claim capacity to second guess executive decision-making and apply simple merits review. Moreover, as shown by Somersett's Case, ${ }^{32}$ there is no locus standi requirement.

29 Thomas Bingham "Should Public Law Remedies be Discretionary?" [1991] PL 67.

30 Minister of Conservation v Maori Land Court [2008] NZCA 564, [2009] 3 NZLR 465.

31 Combined Beneficiaries Union Incorporated v Auckland City COGS Committee [2008] NZCA 423, [2009] 2 NZLR 56.

32 Somersett's Case (1772) 20 State $\operatorname{Tr} 1(\mathrm{~KB})$. 
In Jeffries $v$ Attorney-General ${ }^{33}$ I have suggested that standing in judicial review is in fact a matter of judgment, to be evaluated in the circumstances of the case. Standing, like a duty of care in tort, is in truth not an element of the cause of action; its rejection is a shorthand expression of a conclusion that there are no merits. ${ }^{34}$

Habeas corpus is seen as an exception to the requirement of standing. But that is because in liberty claims the value of the interest at stake is such that the merit threshold is low. Different policies apply elsewhere on the spectrum. And even in habeas cases the remedy will be refused if there is a substantial argument requiring adjudication by other procedures. ${ }^{35}$ Closely adjacent on the spectrum come the human rights claims, to which a more exacting form of review than low intensity Wednesbury, ${ }^{36}$ irrationality is now generally applied in New Zealand as in Canada and Europe. The topic was discussed by Professor Taggart in 2008. ${ }^{37}$

Lower intensity is increasingly appropriate the less the judicial capacity to evaluate the merits and the greater the policy content.

"Non-justiciability" is a convenient but dangerous expression for a bald conclusion - that the court will not intervene. Certainly there are some spheres where intervention is unlikely. Among them are claims that would infringe art 9 of the original Bill of Rights as putting in issue matters of which Parliament is seized. Each limb of Government must accord reasonable freedom of movement to the others. The logic of breach of that simple precept usually does not warrant discussion: the judges are not going to try to inhibit freedom of discussion in Parliament; Parliament is not going to interfere with s 16 of the Judicature Act 1908 which confirms the inherent authority of the courts; neither will seek to inhibit the lawful and reasonable exercise of authority by the Executive.

In some spheres the Court will be especially reluctant to intervene. Certioriari against a particular diplomatic policy is not a likely prospect: the conduct of foreign affairs is par excellence a matter for the Executive. But as the recent Congress discussion in Sydney revealed, across the international board there is a distinct reluctance of judges simply to give carte blanche to claims that the Court has no jurisdiction. The experience elsewhere on the globe of abuse of power has been brutal. Several of the judges present at the Congress had had personal experience of detention and other forms of misconduct directed at them and the processes of their courts. Such experience has given rise to a judicial recognition that ritual hand-washing is an abdication of the judiciary's role to

\footnotetext{
3 Jeffries $v$ Attorney-General [2010] NZCA 38 at [70].

34 Sunset Terraces, above $\mathrm{n} 6$, at [89].

35 Manuel v Superintendent of Hawkes Bay Regional Prison [2005] 1 NZLR 161 (CA).

36 Associated Provincial Picture Houses v Wednesbury Corporation [1948] 1 KB 223 (CA) [Wednesbury].

37 Michael Taggart "Proportionality, Deference, Wednesbury" [2008] NZ L Rev 423.
} 
identify and order relief against illegality. There was a remarkable consensus against the notion of non-justiciability. These themes are also seen in the leading cases in Canada, ${ }^{38}$ and the United Kingdom, ${ }^{39}$ albeit with the exceptions required by a mature judgment of what the public interest requires. ${ }^{40}$

Whether New Zealand should emulate the Conseil D'État or the Australian Administrative Appeals Tribunal and subject administrative decision-making to more exacting review; whether now the High Court is at last rid of minor methamphetamine cases it can deal with such matters with the help where necessary of experts, ${ }^{41}$ warrant discussion beyond the present scope. But the need for systematic and skilled judicial review is beyond argument.

\section{THE INTERNATIONAL SCENE}

The second suggested theme is that it is the function of courts internationally to act in aid of one another and where that is no feasible other dispute resolution systems must be created.

It may be seen by some to challenge the very basis of the Treaty of Westphalia on which the separate jurisdiction of each of the 192 members of the United Nations is proudly established. That point bears elaboration.

In a paper delivered at the Institute for Advanced Legal Studies I argued for cross border cooperation of Judges in the globalised society. ${ }^{42}$ It included the following themes.

The law must, to maintain confidence, keep pace with societal change. Yet among the most conservative in the community are some of its ablest intellectual leaders, the judiciary.

There are powerful reasons for judicial reticence. Judges are the very expression of the nation state:

- $\quad$ appointed by state officials;

- $\quad$ paid from state funds;

38 Amnesty International Canada v Canada (2007) 287 DLR (4 $\left.4^{\text {th }}\right) 35$ (FCC).

$39 R v$ Secretary of State for Foreign and Commonwealth Affairs Ex parte World Development Movement Ltd [1995] 1 WLR 386 (QB), [1995] 1 All ER 611; $R$ v Bow Street Metropolitan Stipendiary Magistrate Ex parte Pinochet Ugarte (No 1) [2000] 1 AC 61 (HL).

$40 \quad R$ (on the application of Corner House Research) v Director of the Serious Fraud Office [2008] UKHL 60, [2009] 1 AC 756.

41 As advocated by Matthew Palmer in respect of Treaty of Waitangi issues. The fundamental need for judges to understand the limitless range of disputes brought before them requires that they be educated in whatever manner is most efficient.

42 Who now is my neighbour? Judicial cooperation across state borders Inner Temple Yearbook 2004-5 1. 
- $\quad$ authorised to apply the force of the state to order specific performance of obligations, impose money damages for their breach, sentence offenders to imprisonment in its prisons; and

- $\quad$ sworn to allegiance to their state or its sovereign.

Further, they are usually members of that state; brought up and educated within its traditions and learned in its law; which within certain limits they may indeed have contributed to making. While judges loathe bias and will normally disqualify themselves rather than expose themselves to risk of it, in the case of the law of their state they are naturally and almost inevitably biased in its favour. That presents no problem where the case concerns events that have happened only in their state, so that there is no cross-border element.

But cases that do contain a cross-border element are another matter. To the idiosyncrasies of the judges in one state must be added, actually or potentially, those of the judges in the other state or states involved. And since there are nearly 200 states, and each state has its own legislature, not to mention differences of culture and religion, the result is a Babel of conflicting laws. Hence of course the title of Dicey and Morris. ${ }^{43}$ Judges' perspective of cross-border transactions is, usually and unsurprisingly, of the differences on which they have to give judgment.

Those who are not judges have a different perspective. For them watching television, driving in Chinese clothing on Arab fuel in a Japanese car to buy bananas from Equador, emailing children abroad, looking up cheap flights, guarding against cancer in ozone depleted sunlight, are all facets of globalisation and realities of everyday life. If they think about it they understand that their community is no longer the nation state of the 17 th century which remains the focus of judges, but something more complex.

The response of legal institutions to that reality has been unsystematic and partial; ${ }^{44}$ it is interesting to consider why.

In truth we all possess a series of concentric personal identities, each of which is in lawyers' terms a mandatory Wednesbury factor - something that must be given its due weight to achieve a just and balanced result. While in some cases, as with Scottish clans, North American bands, Aboriginal peoples and Māori iwi, they can be expressed with more complexity, each of us has at least three:

43 Lord Collins (ed) Dicey, Morris and Collins: Conflict of Laws (14th ed, Sweet and Maxwell, London, 2006).

44 That is despite major international initiatives and institutions, some of which like the World Trade Organisation and the European Union have assumed part of the sovereignty of member states. Among them are or were the Judicial Committee of the Privy Council, the United Nations, the Bretton Woods Agreement, NAFTA, ICAO and the Yen-bloc. The topic of why states voluntarily relinquish aspects of sovereignty to international collectives by entering such agreements as the GATT, GATS, TRIPS and others - whether, in Keynes' term, to avoid more war, or to horse-trade for selfish advantage is controversial. 
(1) as an individual;

(2) as a member of a nation state; and

(3) as a member of the international community.

All of these are important elements of our personal dignity, which the law should promote as far as is consistent with the dignity of others.

\section{A Individual Identity}

Slaves, children and, until very recently, women used to be regarded rather as ancillaries of their dominant free male than as having an identity in their own right. But over the last two centuries, not least because of the excesses of 20th century dictators, in most states modern political and social philosophy pays at least lip service to dignity and security as being a basic entitlement of each individual. ${ }^{45}$ In each civilised state the International Declaration of Human Rights, ${ }^{46}$ and its local applications have brought human rights to everyone's attention. While to give effect to them is a tall order, the moral power of the human rights movement makes it perhaps the dominant expression of globalisation ${ }^{47}$ and an increasingly potent competitor to the autonomy of the nation state. So Senator Pinochet discovered. ${ }^{48}$

\section{B Identity as a Member of a Nation State}

The second form of personal identity is as a member of a state: the governmental entity that is recognised both by state legal systems and by international law which governs relationships among

45 See Ernst-Ulrich Petersmann "From State Sovereignty to the "Sovereignty of Citizens" in the International Relations Law of the EU?" in Neil Walker (ed) Sovereignty in Transition (Hart Publishing, Oxford, 2003) at 144; Jackie Jones "Human Dignity under German Law" [2004] PL 167; Johan Steyn "Guantanamo Bay: The Legal Black Hole" (2004) 53 ICLQ 1 at 6, citing Justice Arbour's "globalisation of the culture of rights": Louise Arbour, Judge of the Supreme Court of Canada "Is the Growth of International Criminal Law a Threat to State Sovereignty?" (Irving R Segal Lecture, University of Pennsylvania, Philadelphia, 24 September 2003).

46 Universal Declaration of Human Rights (adopted 10 December 1948).

47 See for example Archbishop Desmond Tutu "Longford Lecture: The Truth and Reconciliation Process: Restorative Justice" (16 February 2004) Prison Reform Trust <www.prisonreformtrust.org.uk>, in which Tutu challenged the United States and the United Kingdom over the Iraq intervention and advocated international policies of restorative rather than retributive justice. He drew on (at 45):

... an African concept very difficult to render into English as there is no precise equivalent. I refer to Ubuntu/botho. Ubuntu is the essence of being human. We say a person is a person through other persons. We are made for togetherness, to live in a delicate network of interdependence. The totally self-sufficient person is sub-human for none of us comes fully formed into the world. I need other human beings to be human myself... If one person is dehumanised then inexorably we are all diminished and dehumanised in our turn.

$48 \quad R v$ Bow Street Magistrate ex p Pinochet (No 3) [2000] 1 AC 147. See Campbell McLachlan "Pinochet Revisited" (2002) 51 ICLQ 959. 
states. The Westphalian model of independent autonomous states has proved durable: each nation state maintains the power to give or withhold citizenship, to defend its boundaries, to keep order, to impose taxes. In many states its legitimacy derives from regular elections; in others it results from descent or control of the army or both. It can have the virtue of allowing its citizens to make their own decisions about important matters - as with Swiss referenda or with legislative proposals for which mandate is duly sought prior to a general election. It can have the vice that other states are unable or unwilling to intervene when state powers are abused - as at Auschwitz, in Kosovo, in the Congo, and during the gassing of the Marsh Arabs in Iraq. I have described the judges as the very expression of the nation state; they have ordered habeas corpus; ${ }^{49}$ they have also applied the Führerprincip.

\section{Identity as a Member of the International Legal Community}

The third form of personal identity - as a member of the international community - is of its nature diffuse and imprecise. Woodrow Wilson was ridiculed when his League of Nations was not accepted by the United States and failed to prevent the Second World War. The absence of systematic arrangements for an international legislature, executive and judiciary have led some critics such as Dr Kissinger ${ }^{50}$ to treat the state supremacist Machiavelli rather than the idealist Wilson as the guide to reality.

Mr Blair said, in his Iraq speech on 5 March 2004, "the vision of international community is no longer a vision of idealism". ${ }^{51}$ While there is now an element of irony in it, the accuracy of his statement is undeniable. Like the nation state, the international community is a reality. It comprises both the fact of sovereignty of foreign states and the developing norms of international law.

\section{Competing Norms: the Judges' Responsibility}

So three general values systems are in play: those of domestic state sovereignty; those of foreign state sovereignty and internationalism; and those of individual human rights. Despite constant difficulties, ${ }^{52}$ the three forms of human identity are not sealed off but tend to collapse into each

49 Boumediene v Bush 553 US 723 (2008).

50 Henry Kissinger Diplomacy (Simon \& Schuster, New York, 1994).

51 The Times (London, 6 March 2004).

52 The gritty reality of the distinction between the vision of the United Kingdom's Human Rights Act 1998 and its application is discussed by Ruth Costigan, Josephine Sheehan and Philip Thomas The Human Rights Act: an impact study in South Wales (Cardiff Law School, Cardiff, 2004). 
other. When fashioning their own jurisprudence, enlightened final courts refer to international human rights norms and decisions of courts of other states. ${ }^{53}$

There is much room to debate what should be done, by whom, and how far to do it. Contributions can be made by executive governments and by parliaments; by state law reform agencies within the executive or, like the law commissions established on Lord Gardiner's model, outside it; and by international agencies. Each is important. The value of Executive participation in reform, drawing together the legitimacy of involvement and resourcing capacity of the elected government, is obvious; so is the worth of cross-disciplinary contributions, ${ }^{54}$ likewise those of such UN institutions as UNCITRAL, ICAO, WIPO and the ILO; ${ }^{55}$ while the contributions of the Hague Convention and UNIDROIT are also of such importance as to warrant particular mention. But governmental programmes and those of parliaments and other initiating bodies are subject to heavy pressures that can make it impossible for them to deal systematically with necessary reform affecting the operation of the courts. In practice it has been proved irresponsible for judges simply to leave the work of reform to others. ${ }^{56}$ Much of the present topic concerns procedural reform, which is par excellence a judicial responsibility ${ }^{57}$ although crossing into the substantial topic of jurisdiction. 58

There was for a long time in the common law a strange pretence that "the law" was always there and the judges did no more than undertake search for it. But that was both nonsensical and uncandid. The law was and is a human construct. To the extent existing jurisprudence does not cover a case the judges have to decide whether they should add to it and, if so, what and how.

53 The South African death penalty case State v Makwanyane [1995] 1 LRC 269 is one outstanding example, now widely cited; the majority judgment of the United States homosexual rights case Lawrence v Texas 538 US 1 (2003) is another.

54 It also brings anxiety - if we think our predecessors were blind and deaf to what so obviously needs attention, what are our successors going to say about us?

55 See the report of a proposed new international work code for mariners discussed in January 2004: Le Monde (Paris, 27 January 2004) at 20.

56 While critics complain of judicial activism the alternative is inaction and the injustice that results from failure to respond to altered conditions. As usual in human affairs, sense tends to lie between extremes.

57 See Jorgensen $v$ News Media Ltd [1969] NZLR 961 (CA) (evidence - admission at defamation trial of evidence of conviction for murder); and Davis v McKnight [1968] NZLR 1164 (CA) (procedure consolidation of proceedings), in each of which the leading judgment in the Court of Appeal was delivered by Turner $\mathrm{J}$.

58 Sir Jack Jacob Private International Litigation (Longman, London, 1988). The cautionary tale of Harris $v$ Taylor [1915] 2 KB 580 (KB) and Henry v Geoprosco International Ltd [1976] QB 726 (QB), where an appearance to protest jurisdiction was held to concede it, is mentioned (at 9-10) and underlines the need for modern judges to accept responsibility for dispelling ghouls of the past. (Compare Kuwait Asia Bank EC v National Mutual Life Nominees Ltd [1991] 1 AC 187 (PC)). See also James J Fawcett (ed) Declining Jurisdiction in Private International Law (Clarendon Press, Oxford, 1995). 
In domestic law there are powerful reasons for judicial reticence, expressed in the prohibition by the French Code Civile of judge-made law. In common law states, even though the entire common law is judge-made, it is of course the legislature which, unlike the courts, has the legitimacy of being publicly elected. Yet as Sir John Laws of the English Court of Appeal has observed in "Democracy's Illusions: challenges to the rule of law":59

$\ldots$ democracy $\ldots$ is an antidote against tyranny and, although not perfect, it is largely effective. But to prevent its dangers, and despite the difficulties posed by giving power to unelected judges, democracy needs to be moderated by the rule of law ...

The rule of law now stands for the standards of decency required to protect the value of human dignity which, especially since the Second World War, has justified an increased public concern for human rights.

I have concluded that judges have frequent opportunities to face the realities that to date have received insufficient attention; and they should now set about doing so systematically.

We have recently seen my court faced, in a matter of months, with calls to interpret and apply the Refugee Convention, ${ }^{60}$ the Hague Convention on Child Abduction, ${ }^{61}$ the Hague Rules on Carriage by Sea ${ }^{62}$ principles of international criminal law, ${ }^{63}$ the international application of the penal law of Poland ${ }^{64}$ and the reverse: service abroad of criminal process, ${ }^{65}$ and the application of our criminal law overseas. ${ }^{66}$ Each of these has required us to contribute to the jurisprudence of public international law.

I deny that cross-border co-operation is inconsistent with the State sovereignty which is of such importance to us. It is by wise exercise of that jurisdiction within their own state for which they have responsibility both domestically and under international law that the judicial leaders of crossborder judicial co-operation have dealt effectively with the injustices flowing from a former myopic approach.

59 Sir John Laws "Democracy's Illusions: Challenges to the Rule of Law" Inner Temple Yearbook 2010-2011 100 .

60 Tamil X v Refugee Status Appeals Authority [2009] NZCA 488, [2010] 2 NZLR 73.

61 Fairfax v Ireton [2009] NZCA 100, [2009] 3 NZLR 289.

62 Tasman Orient Line CVv New Zealand China Clays Ltd (The Tasman Orient) [2009] NZCA 135, [2009] 3 NZLR 58; reversed [2009] NZSC 37; discussed by Paul Myberg [2010] LMCLQ 569.

63 Tamil X v Refugee Status Appeals Authority, above n 57.

64 Bujak v The District Court at Christchurch [2009] NZCA 257.

65 Civil Aviation Authority v Heavylift Cargo Airlines Pty Ltd [2008] NZCA 76, [2008] 2 NZLR 391.

66 Standard 304 Ltd $v$ R [2008] NZCA 563 [2010] NZAR 194. 
An unhappy example is the decision of the Privy Council in Mercedes Benz. ${ }^{67}$ There a Monagasque fraudster in Monaco obtained moneys from Mercedes Benz by deception. Mercedes Benz discovered that the fraudster had funds in a bank account in Hong Kong and applied for an order freezing them until substantive judgment could be obtained and then enforced against the fund. The Privy Council on appeal from Hong Kong dismissed the procedural claim by Mercedes Benz, reasoning that because Hong Kong had no jurisdiction to determine the substantive claim of fraud it lacked the power to freeze the fraudster's assets pending substantive judgment elsewhere. Whether or not sustainable in terms of the black letter of Hong Kong rules of court the result was wrong in principle:

(1) The result is inconsistent with the principle of comity which is the way ahead for international application of the rule of law.

(2) The function of rules of court is to assist the due administration of justice. Like other adjectival rules they are to be read purposefully.

(3) On this international plain we must look to the greater good. How is this to be identified?

A powerful subcommittee of the Rules Committee made proposals to replace our High Court Rules on the topic, which dated back to the original English Judicature Act, with a principled update. The result adopts the standard of a good international citizen. ${ }^{68}$ It has attracted favourable attention elsewhere,

\section{CONVERGENCE OF THE THEMES}

With the evaporation of the neo-liberal recipe for social well-being, illustrated domestically by the disaster of the leaky building epidemic, I have concluded that for a true guide we need a more serious principle for judicial review and for forming an international perspective than either the "reasonableness" tautology of Lord Greene in Wednesbury or unguided pragmatism. We should search for principle.

67 Mercedes-Benz AG v Leiduck [1996] AC 284 (PC).

68 The High Court Rules now state:

7.81 Interim relief in support of overseas proceedings

(1) On the application of a party or an intended party to judicial proceedings commenced or to be commenced outside New Zealand (overseas proceedings), the court may, if the court thinks it just to do so, give interim relief in support of the overseas proceedings.

See also: $r$ 32.5(1)(b) which now states expressly that the Court may make a freezing order if an applicant has a good arguable case on an accrued or prospective cause of action that is justiciable in "another court". The definition of "another court" includes a foreign court: $\mathrm{r} 32.1$. 
New Zealand has set standards in many areas. Our blind following of others' doctrines in the Building Act 1991 and related policies took us up a false and costly path. It is time for us to rethink and to do so in the areas the subject of this address.

Best practice in otherwise unrelated spheres provides some interesting pointers. When a criminal judge recognises that in sentencing a mother the needs of her dependent children must be considered, the Court is exhibiting the utmost respect for fellow human beings. ${ }^{69}$ When the Supreme Court in determining an appeal against deportation takes into account the interests of dependent New Zealand citizen children, again it is exhibiting the utmost respect for fellow human beings. ${ }^{70}$ I will come to some other examples of this approach. But I observe that it is easier for New Zealanders to adopt such a standard in public law, concerning performance of the state's role, than it was for the Australian, Lord Atkin, to adapt the "neighbour" principle into a private law tort.

The notion of utmost respect for fellow human beings captures precisely the concept of equality, used by the Constitutional Court of Italy to strike down laws that would have exempted Signor Berlusconi from liability to which every other citizen was subject; ${ }^{71}$ it expresses the standard set down for the Crown's conduct of litigation in Miss Alice. ${ }^{72}$ It is an expression of human dignity. It happens to fit within the "justice" component of the judicial oath. And in terms of our approach to international issues it has an admirable export potential: it expresses the answer the Rules Committee gave to the Mercedes Benz problem and the concept of comity that is rapidly overtaking state isolation even in areas of policing and tax. ${ }^{73}$

The substantive result is what matters. It recognises that public law, both domestic and as affecting international transactions, concerns dignity and decency.

I have been using the English circumlocution "utmost respect for fellow human beings" for a concept for which at a recent judges' conference Professor Angelo has used the single Māori word "aroha". To introduce "aroha" directly into New Zealand law might well startle the horses, even if objectively the contribution from a Māori provenance is better suited to New Zealand conditions than any external competitor. The forthcoming change in New Zealand demographics recounted, with acknowledgement to Justice Joseph Williams, in "A Second-Hand Rose? Creating a New Zealand Jurisprudence", ${ }^{74}$ may be thought likely to alter that. But for the time being I invite you to

$69 S v M[2007] \mathrm{ZACC} 18$.

70 Ye v Minister of Immigration [2009] NZSC 76, [2010] NZLR 104.

71 Judgment no 262 of 2009, 19 October 2009. It may be a pointer to whether Māori should have lesser rights than others in relation to coastal properties.

72 Solicitor-General v Miss Alice [2007] 2 NZLR 783 (HC) at [42]-[52].

73 Avowal Administrative Attorneys Ltd v District Court at North Shore [2008] 1 NZLR 675; on appeal [2010] NZCA 183; compare Government of India v Taylor [1955] AC 491 (HL).

74 Baragwanath "A Second-Hand Rose? Creating a New Zealand Jurisprudence", above n 3. 
consider whether the circumlocution does not in fact express the essential underlying idea and warrant adoption as a synthesising principle for these vital and dynamic areas of our legal development - domestically and internationally.

I conclude with a personal note. My plans for the future include periods here and elsewhere examining the topic of citizen and state. I could not have embarked upon it without the experience Wellington has given me - as counsel, at the Law Commission, in appearances before Select Committees of Parliament, and as a judge - of meeting a wide range of interesting people who make, administer, teach and debate our laws. It continues to be stimulating and enjoyable. I am most grateful for the many kindnesses of this university and its community. 
